\title{
Inter-relationship between abusive supervision, distributive justice, intention to leave and workplace deviance: An affective process view
}

\author{
Amirul Hasan Ansari ${ }^{1}$, Yusra Iqbal ${ }^{2 *}$ \\ ${ }^{1}$ Director, ${ }^{2}$ Research Scholar, Centre for Management Studies, Jamia Millia Islamia, New Delhi, India \\ *Corresponding Author: Yusra Iqbal \\ Email: yusra.syed.iqbal@gmail.com
}

\begin{abstract}
Aim: The aim of the study is to develop a theoretical model to depict the relationship between abusive supervision, distributive justice, intention to leave and workplace deviance and the affective processes involved in them.

Methodology: A literature review of the relevant variables was done.

Results: The literature review indicated that though strong interrelationships exist both between the variables being studied and the affective processes involved but as yet no theoretical model exists.

Conclusion: The study was successful in creating a theoretical model to show the inter relation between abusive supervision, distributive justice, intention to leave and workplace deviance and the role of subordinate's negative reciprocity belief, power distance perception and feeling of loss of control over circumstances.
\end{abstract}

Keywords: Abusive supervision, Distributive justice, Intention to leave, Workplace deviance, Negative reciprocity, Power distance, Reactance.

\section{Introduction}

People are the main assets of an organisation and their commitment and loyalty is responsible for the success of any organisation. When any organisational factor adversely affects the feeling of wellbeing in the employees it also negatively affects the well being of the organisation. One of the major factors that has a major effect on the smooth running of the organisation is Abusive supervision. ${ }^{1}$ Although, abusive supervision is latent in the organisation but it has far reaching negative impact. ${ }^{2}$ It affects subordinate behaviour in relation to all major organisational variables. Abusive supervision has been studied from the perspective of justice, the most basic and obvious of which is distributive justice. Abusive supervision ${ }^{3}$ and distributive justice ${ }^{4}$ have both been an important cause behind employees' intention to leave the organisation, which carries an unhealthy cost for the organisation. Several researches have shown that employee deviance originates with abusive supervision. ${ }^{5}$ Intention to leave also cause the reduction in Power distance between the Abusive supervisor and abused subordinate, with little fear of cost of retaliation, the subordinate often indulge in deviant behaviour in the workplace. Workplace deviance has been thought to be major problem in any organisation ${ }^{6}$ Thus, it becomes imperative to study and understand the problem and the affective functions operating in its background, so that with better understanding it can be dealt with more efficiently in future.

\section{Review of Literature Abusive Supervision}

Abusive supervision has most succinctly been defined by Tepper ${ }^{7}$ as 'subordinates' perceptions of the extent to which their supervisors engage in the sustained display of hostile verbal and nonverbal behaviours, excluding physical contact'. This abusive behaviour originates from the misuse of power and authority which is vested in a supervisor, and is used to mistreat the subordinate in a number of ways. ${ }^{8}$

This mistreatment can be of different kinds starting from outright intimidation, humiliation, ridicule, using derogatory names to withholding important information. ${ }^{9}$ It can also take the form of supervisor stealing credit from subordinates, lying to them or giving silent treatment etc. ${ }^{7}$

A number of studies have been done on Abusive supervision $^{7,10-12}$ to examine its impact on subordinate behaviour. Several studies have shown that abusive supervision and subordinates' performance of workplace deviance are related. ${ }^{10,13-18}$

Empirical research has mostly examined abuse from the subordinate's perspective ${ }^{8,19,7,11,16}$ as abusive supervision can only be a subjective assessment by the subordinate to measure counterproductive behaviour ${ }^{16,20-22}$ by the supervisor.

The subordinates' perceptions of unfairness determine their response to abusive supervision. ${ }^{7}$

The power difference in the relation between supervisor and subordinate ensures that abusive supervision does not transform into a tit for tat retaliation spiral between the two, as thought of consequences does not let people retaliate overtly against actions of a powerful abuser. ${ }^{23}$ So, in order to make their workplace circumstances align with their expectations $^{8}$ and regain the feeling of control over their circumstances, abused subordinates reduce actions that benefit the organization and its representatives.

The literature on Abusive supervision and Deviance has followed Justice and Reactance Theory. The Justice perspective towards Abusive supervision and Interpersonal and Organisational Deviance includes the Negative Reciprocity beliefs of the subordinate ${ }^{16}$ and also suggests that subordinates retaliate against the perceived unfairness of the abusive supervisor's behaviour by reducing positive behaviour in the organisation. ${ }^{19,7}$ Several researches have 
suggested that employees who feel threatened in their workplace strive to preserve a sense of autonomy. ${ }^{24,25}$ Reactance is an unpleasant motivational arousal experienced as a result of threat of or loss of carefree behaviours and it leads to the desire to regain control. ${ }^{24}$ The reactance theory perspective towards abusive supervision and deviance also suggests that subordinates under abusive supervision feel little to no control on their situation, and to restore their autonomy reduce their organisational citizenship behaviours. ${ }^{11}$

\section{Workplace Deviance}

Workplace deviance has been defined as behaviour which not only violates organizational norms but also deliberately harms the organization and/or its employees. ${ }^{26}$ It is a recurring and costly problem in most organisations. ${ }^{26}$

Earlier research showed that majority of employees engaged in some or the other form of deviant behaviour. ${ }^{27-30}$

Interpersonal treatment is a major factor behind deviant behaviour of the subordinate in the workplace. ${ }^{31}$ Tepper found that since abusive supervision adversely effects the perceptions of justice, it leads to workplace deviance. ${ }^{7}$

In face of abusive supervision, employees may respond by either directly retaliating against their source of abuse i.e. the supervisor or they may engage in displaced deviance by targeting the organization or other colleagues. ${ }^{16}$ So, workplace deviance occurs mostly due to displaced aggression. ${ }^{16}$ The primary reason for displaced aggression is that the source of abuse and injustice may not be available to retaliate against or the abused subordinate may sense that retaliating against the supervisor will not stop the abuse and may even lead to even more hostility on the instigator's part. $^{10}$

In both these cases direct retaliation of the subordinate against abusive supervision is curbed ${ }^{32}$ and revenge in form of deviance is directed to less powerful targets ${ }^{33}$ like the coworkers or the organisation at large.

Following this line of thinking, Robinson and Bennett categorized workplace deviance into organizational and interpersonal deviance. ${ }^{34}$

\section{Distributive Justice}

Equity theory of Adams suggest that individuals need to maintain a perception that their social world is just and predictable. ${ }^{35}$ Adams first defined distributive justice by proposing that people assess the fairness of outcome distribution by comparing their contributions and outcomes against that of a referent. ${ }^{36-39}$ It is expected that behaviour arising out of a feeling of inequity would be directed towards regaining the feeling of equity. ${ }^{35}$ In case of individual's perception of inequity in face of abusive supervision, the attempt towards restoration of equity can take the form of deviance at interpersonal or organisational level.

Distributive injustice is an important reason behind employees committing theft, sabotage, or mutilation in the workplace because they feel that their just dues have not been received and the organization owes them. ${ }^{40}$ This perceived inequity is the major cause of property and production deviance by the employee in a variety of industries. ${ }^{41}$

Greenberg, however, reported that employees did not respond to insensitive and disrespectful personal treatment when they perceive justice in the final outcome. ${ }^{42}$ Studies have also indicated that workplace deviance, arising out of the subordinate's desire for revenge or to feel in control of their circumstances, is higher in case of multiple unfair events. $^{43,44}$

This leads the researcher to believe that distributive justice plays an important role in managing workplace deviance.

\section{Intention to Leave}

Past researches have shown that intention to leave is a strong indicator of employee turnover. ${ }^{45,46} \mathrm{~A}$ high turnover is a major problem for any organisation ${ }^{47}$ as recruitment and training of new people costs the organisation in many ways.

According to Tepper abusive supervision increases turnover intention. ${ }^{7}$ Negative experience of abusive supervision in the workplace makes the subordinates question whether they should continue in the organisation. ${ }^{3}$

Studies also show that in in case of low distributive justice employees chose to quit their job in order to end the inequity. ${ }^{48-50,4}$

Power distance is also an important factor in deciding the strength of relation between subordinate's intention to quit and his deviant behaviour in the workplace. Power distance refers to the degree to which individuals, groups, or societies accept that inequalities of power, status and wealth are unavoidable, legitimate, or functional. ${ }^{51}$ This degree of acceptance of the inequality in power decides how individuals at different levels of power interact. ${ }^{52}$ Higher power distance is associated with higher deference ${ }^{53}$ while lower power distance will mean less deference towards authority figures. ${ }^{52}$ The results of a Seminal study by Tepper et al. also indicated that abusive supervision is more strongly associated with subordinates' organization deviance and supervisor directed deviance when subordinates' intention to quit is higher. ${ }^{21}$

\section{Research Gap}

The literature review has shown the interrelationship between abusive supervision, distributive justice, intention to leave and workplace deviance. However, no conceptual model has been developed till date to comprehensively depict these relationships keeping in view the affective processes of the subordinate.

\section{Methodology}

This is a conceptual paper which aims to put forward a theoretical model to depict the inter relationship between Abusive supervision, distributive justice, intention to leave and workplace deviance in conjugation with the affective process of the abused subordinate, as shown in Fig. 1. 


\section{Results}

The theoretical model to depict the inter relationship between abusive supervision, distributive justice, intention to leave and workplace deviance in conjugation with the affective process of the abused subordinate, is shown in Fig. 1.

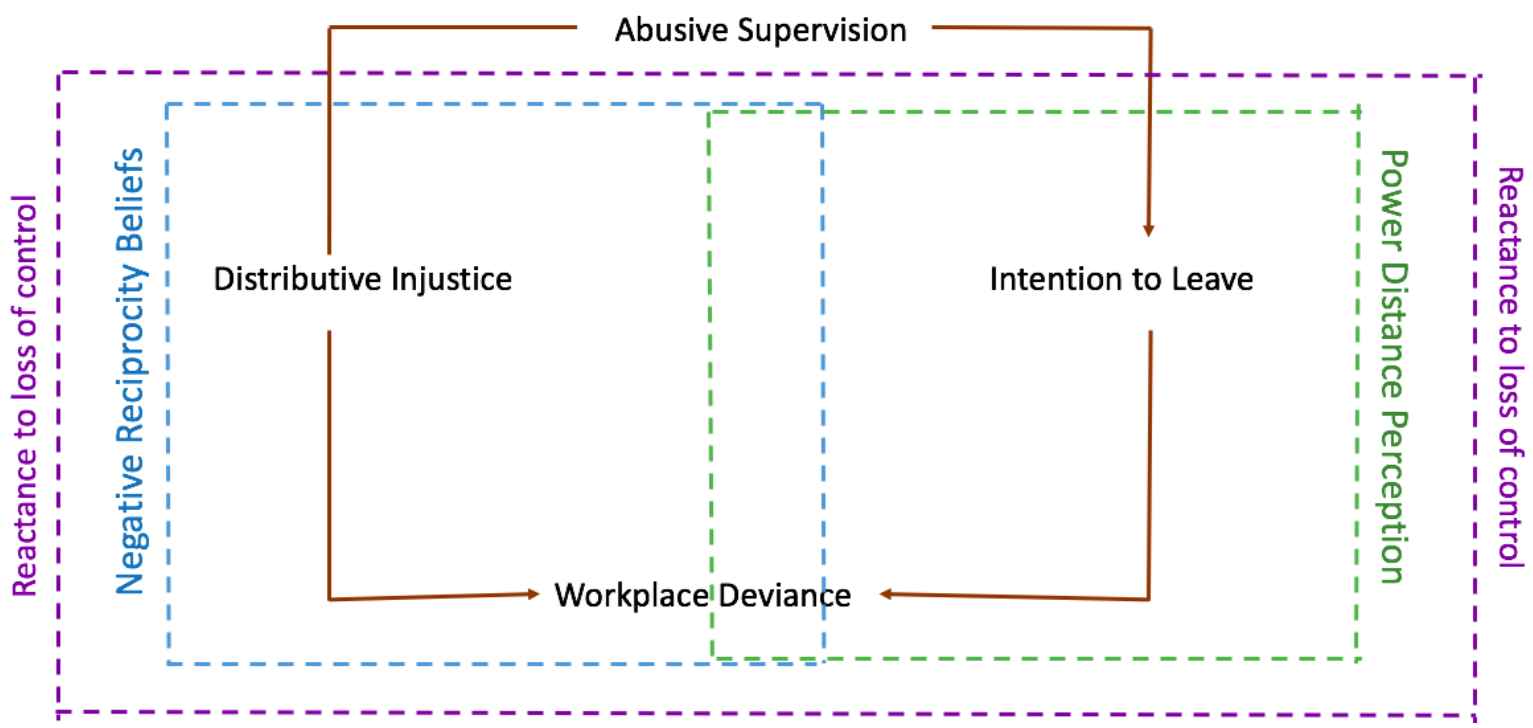

Fig. 1: Shows the inter relationship between abusive supervision, distributive justice, intention to leave and workplace deviance in view of Negative reciprocity beliefs, Power distance perception and Reactance to loss of control of the subordinate

Keeping in view the literature review presented in the previous section, Fig. 1 shows that Abusive supervision in combination with low distributive justice leads to either outright Workplace Deviance or a reduction in Organisational Citizenship behaviour. This happens with the background of well-established negative reciprocity beliefs of the abused subordinate. ${ }^{16}$ This belief that any unjust and insensitive action of the supervisor has to be paid back in kind in some way ensures a strong positive relation between Abusive supervision, distributive injustice and deviance

Similarly, abusive supervision can make the employee question their desire to be part of the organisation, leading to an intention to quit their job. This leads to a decrease in power distance between the abusive supervisor and the abused subordinate, leading to more likelihood of him being deviant in the workplace. ${ }^{21}$

Since, abusive supervision leads the subordinate to perceive a loss of control over his circumstances, most of the response behaviour is motivated by the desire to regain control. ${ }^{11}$

All these affective processes of the subordinate have well established regions of overlap since they all occur in a person in response to a single stimuli of abusive supervision.

Understanding the affective process following Abusive supervision and the behavioural response originating from it, can go a long way in minimising damage to the organisation.

Conflict of Interest: None.

\section{References}

1. Hershcovis MS, Barling J. Towards a multi-foci approach to workplace aggression: A meta-analytic review of outcomes from different perpetrators. J Organ Behav 2010;31(1):24-44.

2. Harris KJ, Harvey P, Kacmar KM. Abusive supervisory reactions to coworker relationship conflict. Leadersh $Q$ 2011;22(5):1010-23.

3. Turnley WH, Feldman DC. The impact of psychological contract violations on exit, voice, loyalty, and neglect. Hum Relat 1999;52(7):895-22.

4. Loi R, Hang-Yue N, Foley S. Linking employees' justice perceptions to organizational commitment and intention to leave: The mediating role of perceived organizational support. J Occup Organ Psychol 2006;79:101-20.

5. Ashforth B. Petty tyranny in organizations. Hum Relat 1994;47(7):755-78.

6. Liu J, Kwong Kwan H, Wu LZ, Wu W. Abusive supervision and subordinate supervisor-directed deviance: The moderating role of traditional values and the mediating role of revenge cognitions. J Occup Organ Psychol 2010;83(4):835-56.

7. Tepper BJ. Consequences of abusive supervision. Acad Manage J 2000;43(2):178-90.

8. Ashforth BE. Petty tyranny in organizations: A preliminary examination of antecedents and consequences. Can J Adm Sci 1997;14(2):126-40.

9. Keashly L. Emotional abuse in the workplace: Conceptual and empirical issues. Journal of emotional abuse. 1997;1(1):85117.

10. Tepper BJ, Duffy MK, Shaw JD. Personality moderators of the relationship between abusive supervision and subordinates' resistance. J Appl Psychol 2001;86(5):974-83.

11. Zellars KL, Tepper BJ, Duffy MK. Abusive supervision and subordinates' organizational citizenship behavior. J Appl Psychol. 2002;87(6): 1068-76.

12. Tepper BJ, Duffy MK, Hoobler J, Ensley MD. Moderators of the relationships between coworkers' organizational citizenship 
behavior and fellow employees' attitudes. J Appl Psychol 2004;89(3):455-65.

13. Detert JR, Treviño LK, Burris ER, Andiappan M. Managerial modes of influence and counterproductivity in organizations: A longitudinal business-unit-level investigation. J Appl Psychol 2007;92(4):993-1005.

14. Duffy MK, Ganster DC, Pagon M. Social undermining and social support in the workplace. Acad Manage $J$ 2002;45(2):331-51.

15. Dupré KE, Inness M, Connelly CE, Barling J, Hoption C. Workplace aggression in teenage part-time employees. J Appl Psychol 2006;91(5):987.

16. Mitchell MS, Ambrose ML. Abusive supervision and workplace deviance and the moderating effects of negative reciprocity beliefs. J Appl Psychol 2007;92(4):1159-68.

17. Tepper BJ, Henle CA, Lambert LS, Giacalone RA, Duffy MK. Abusive supervision and subordinates' organization deviance. $J$ Appl Psychol 2008;93(4):721-32.

18. Thau S, Bennett RJ, Mitchell MS, Marrs MB. How management style moderates the relationship between abusive supervision and workplace deviance: An uncertainty management theory perspective. Organ Behav Hum Decis Process 2009;108(1):79-92.

19. Tepper BJ, Eisenbach RJ, Kirby SL, Potter PW. Test of a justice-based model of subordinates' resistance to downward influence attempts. Group Organ Manag 1998;23(2):144-60.

20. Aryee S, Chen ZX, Sun LY, Debrah YA. Antecedents and outcomes of abusive supervision: test of a trickle-down model. J Appl Psychol 2007;92(1):191-201.

21. Tepper BJ, Carr JC, Breaux DM, Geider S, Hu C, Hua W. Abusive supervision, intentions to quit, and employees' workplace deviance: A power/dependence analysis. Organ Behav Hum Decis Process 2009;109(2):156-67.

22. Restubog SL, Scott KL, Zagenczyk TJ. When distress hits home: The role of contextual factors and psychological distress in predicting employees' responses to abusive supervision. $J$ Appl Psychol 2011;96(4):713-29.

23. Lord VB. Characteristics of violence in state government. $J$ Interpers Violence 1998;13(4):489-503.

24. Brehm JW. A theory of psychological reactance. New York: Academic Press; 1966.

25. Wright RA, Brehm SS. Reactance as impression management: A critical review. J Pers Soc Psychol 1982;42(4):608-18.

26. Bennett RJ, Robinson SL. The past, present, and future of workplace deviance research. In: Greenberg J, editor. Organizational behavior: The state of science. 2nd ed. Mahwah, (NJ): Erlbaum; 2003.p. 247-81.

27. Harper D. Spotlight abuse-save profits. Ind Distrib 1990;79(3):47-51.

28. Slora KB. An empirical approach to determining employee deviance base rates. J Bus Psychol 1989;4(2):199-219.

29. Bennett RJ, Robinson SL. Development of a measure of workplace deviance. J Appl Psychol 2000;85(3):349-60.

30. Harris LC, Ogbonna E. Exploring service sabotage: The antecedents, types and consequences of frontline, deviant, antiservice behaviors. J Serv Res 2002;4(3):163-83.

31. Robinson SL, Greenberg J. Employees behaving badly: Dimensions, determinants and dilemmas in the study of workplace deviance. In: Cooper CL, Rousseau DM, editors. Trends in organizational behaviour. New York: John Wiley \& Sons Ltd.; 1998.p.1-30.

32. Baron RA. Magnitude of victim's pain cues and level of prior anger arousal as determinants of adult aggressive behavior. $J$ Pers Soc Psychol 1971;17(3):236-43.

33. Miller NE.I. The frustration-aggression hypothesis. Psychol Rev 1941;48(4):337-42.
34. Robinson SL, Bennett RJ. A typology of deviant workplace behaviors: A multidimensional scaling study. Acad Manage $J$ 1995;1;38(2):555-72.

35. Adams JS. Towards an understanding of inequity. J Abnorm Soc Psychol 1963;67(5):422-36.

36. Adams JS. Inequity in social exchange. Adv Exp Soc Psychol 1965;2:267-99.

37. Cropanzano R, Greenberg J. Progress in organizational justice: Tunneling through the maze. In: Cooper CL, Robertson IT, editors. International review of industrial and organizational psychology. New York: John Wiley \& Sons;1997. p.317-72.

38. Homans GC. Social behavior: Its elementary forms. Oxford, England: Harcourt, Brace; 1961.

39. Kulik CT, Ambrose ML. Personal and situational determinants of referent choice. Acad Manage Rev 1992;17(2):212-37.

40. Sieh EW. Garment workers: Perceptions of inequity and employee theft. Br J Criminol 1987 Mar 1;27(2):174-90.

41. Hollinger RC, Clark JP. Theft by employees. Lexington (MA): Lexington Books; 1983.

42. Greenberg J. The social side of fairness: Interpersonal and informational classes of organizational justice. In: R. Cropanzano, editor. Justice in the workplace: Approaching fairness in human resource management. Hillsdale (NJ): Lawrence Erlbaum Associates; 1993.p. 79-103.

43. Tripp TM, Bies RJ. Getting even: The truth about workplace revenge--and how to stop it. San Francisco (CA): Jossey-Bass, John Wiley \& Sons; 2009.

44. Skarlicki DP, Folger R. Retaliation in the workplace: The roles of distributive, procedural, and interactional justice. $J$ Appl Psychol 1997;82(3):434-43.

45. Porter LW, Steers RM. Organizational, work, and personal factors in employee turnover and absenteeism. Psychol Bull 1973;80(2):151-76.

46. Griffeth RW, Hom PW, Gaertner S. A meta-analysis of antecedents and correlates of employee turnover: Update, moderator tests, and research implications for the next millennium. J Manage 2000;26(3):463-88.

47. Mitchell TR, Holtom BC, Lee TW, Sablynski CJ, Erez M. Why people stay: Using job embeddedness to predict voluntary turnover. Acad Manage J 2001;44(6):1102-21.

48. Hom PW, Griffeth RW, Sellaro CL. The validity of Mobley's (1977) model of employee turnover. Organ Behav Hum Perform 1984;34(2):141-74.

49. Hetidrix WH, Robbins T, Miller J, Summers TP. Effects of Procedural and Distributive Justice on Factors Predictive of turnover. J Soc Behav Pers 1998;13(4):611-32.

50. Fields D, Pang M, Chiu C. Distributive and procedural justice as predictors of employee outcomes in Hong Kong. J Organ Behav 2000;21(5):547-62.

51. Hofstede G. Dimensionalizing Cultures: The Hofstede Model in Context. Online Readings Psychol Culture 2011;2(1).

52. Javidan M, House RJ. Cultural acumen for the global manager: Lessons from project GLOBE. Organ Dyn 2001;29(4):289305.

53. Yang J, Mossholder K W, Peng TK. Procedural justice climate and group power distance: An examination of cross-level interaction effects. J Appl Psychol 2007;92(3):681-92.

How to cite this article: Ansari $\mathrm{AH}$, Iqbal Y. Interrelationship between abusive supervision, distributive justice, intention to leave and workplace deviance: An affective process view. J Manag Res Anal 2019;6(2):112-5. 